Jurnal Pengabdian kepada Masyarakat

\title{
Analisis Persoalan dan Solusi Keberlanjutan UKM: Studi Kasus pada Usaha Karyawan PHK di Kota Balikpapan
}

\author{
Hasto Finanto, Dessi Handasari, Totok Ismawanto, Saiful Ghozi \\ Jurusan Akuntansi, Politeknik Negeri Balikpapan \\ *hasto.finanto@poltekba.ac.id
}

\begin{abstract}
Kata Abstrak Artikel ini memberikan analisis situasi dan kebutuhan solusi kepada usaha Kunci: $\quad$ yang didirikan oleh karyawan yang kena dampak PHK. Usaha yang didirikan merupakan usaha baru yang masuk kategori Usaha Kecil dan Menengah (UKM). Usaha yang didirikan oleh mitra tersebut sejauh ini tidak berjalan dengan baik karena dan tidak menghasilkan cashflow yang stabil. Bahkan mitra mengeluhkan masih merugi. Menengah, Banyak produksi yang dipasarkan mengalamai return karena system penjualanny Analisis masih sistem titip di warung/ toko dan tidak laku. Solusi yang diajukan terbagi dalam persoalan, beberapa hal, yaitu manajerial, akses permodalan, dan implentasi teknologi pemasaran. Analisis eksplorasi dan dokumentasi tawaran solusi sesuai kondisi mitra saat pengambilan data. Oleh karena itu tingkat kebutuhan solusi dapat sewaktu- waktu berubah sesuai dinamika di lapangan.
\end{abstract}

Keywords: $\quad$ Abstract This article provides an analysis of the situation and the need for solutions to Small and businesses founded by employees who were affected by the layoffs. The business that Medium was established was a new business that was categorized as Small and Medium Enterprises Enterprises (SME). The business established by this partner has so far not been going well because it has not generated a stable cash flow. Even SME partners stated that they are still losing money. Many products that are marketed experience a return because the sales system is still in the stalls / shops and does not sell well. The proposed solution is divided into several things, namely management, capital access, marketing, distribution and production technology

\section{PENDAHULUAN}

Kondisi pandemi virus Covid-19 yang terjadi di berbagai daerah Indonesia telah berimbas pada aspek sosio ekonomi sehingga beberapa perusahaan melakukan PHK dan pengurangan karyawan. Demikian juga di kota Balikpapan, Kalimantan Timur. Dalam rangka tuntutan keberlanjutan ekonomi karyawan pasca PHK maupun pengurangan jam kerja, maka diperlukan stimulus bagi keberlanjutan inovasi usaha sehingga survive dalam rangka memenuhi kebutuhan ekonomidalam kondisi pandemi. Termasuk pada karyawan yang mengalami pengurangan jam kerja, mereka perlu menyiasati penurunan upah/ gajimelalui pemberdayaan waktu luangnya agar tetap produktif.

Artikel ini memberikan analisis situasi dan kebutuhan solusi atas usaha yang didirikan oleh karyawan yang kena kebijakan PHK perusahaan. Usaha yang didirikan merupakan usaha baru yang masuk kategori Usaha Kecil dan Menengah (UKM). Selanjutnya pengusaha tersebut kami sebut sebagai mitra. 
Usaha yang digeluti mitra adalah pembuatan aneka jenis roti. Usaha dimulai bulan Juni 2020 setelah mengalami PHK dari salahsatu perusahaan tambang. Sedangkan istrinya mantan perawat yang terkena dampak pengurangan karyawan klinik kesehatan di kota Balikpapan. Usaha Bakery diawali dengan bermodalkan uang PHK dan uang Jamsostek. Jumlah tenaga kerja yang terlibat adalah 3 orang, yang terdiri dari suami-istri dan tenaga non produktif yang tinggal berdekatan dengan mitra. Diawal usaha mitra telah melakukan beberapa investasi yakni investasi peralatan khusus: \pm Rp. 20.000.000, nnvestasi bagunan dapur semi permanen: \pm Rp. 20.000.000, serta investasi bahan baku dan bahan habis tergantung order. Produksi regular miytra adalah Roti manis Rp. 5.000 dan Rp. Rp. 7.000 per biji denag kapasitas pesanan 500 pcs perhari. Diperkirakan omzet yang dicapai sejauh ini \pm Rp.9.000.000

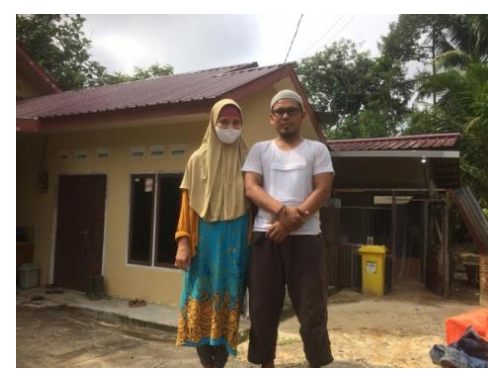

a. Pemilik UKM di derpan rumah usaha

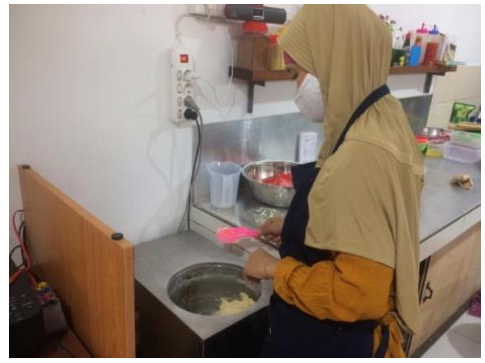

c. Lokasi dapur produksi

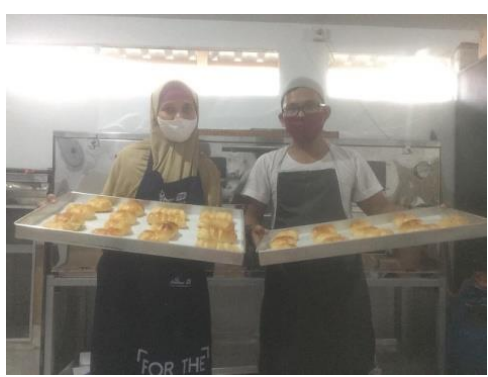

b. Varian utama produksi UKM

Gambar 1 Profil Mitra-Objek Analisis

Sayangnya, usaha yang didirikan oleh mitra tersebut sejauh ini tidak berjalan dengan baik karena tidak menghasilkan cashflow yang stabil. Bahkan mitra mengeluhkan masih merugi. Banyak produksi yang dipasarkan mengalamai return atau kembali karena system penjualanny masih system titip di warung/toko dan tidak laku. Salahsatu strategi untuk memberikan solusi pada masalah serupa adalah pengembangan industri rumah tangga Roti Tanjong di Kecamatan Samalanga Kabupaten Bireuen. Dimana berdasarkan analisis matriks Quantitative Strategic Planning Matrix (QSP) didapatkan hasil bahwa perbaikan sarana dan prasarana produksi, dan sumber daya manusia serta penanaman modal swasta berhasil meningkatkan daya tahan dan ekspansi usaha (Afridhal, 2017). Selain itu, pentingnya membangun teknologi manajemen keuangan UKM yang sederhana diharapkan akan mampu membangun efisiensi usaha mitra (Lape Ngatu, 2019). Perkembangan teknologi pemasaran digital juga menjadi potensi besar bagi UMKM dalam meningkatkan omset dan strategi penjualan (Efriyenty Hikmah; Khadijah, 
Khadijah, 2021). Untuk itu dalam studi ini akan dilakukan analisis permasalahan dan tawaran solusi pengembangan usaha yang dijalankan oleh mitra sesuai literartur dan kondisi mitra.

\section{METODOLOGI}

Penelitian ini merupakan studi eksplorasi atas kondisi usaha UKM baru dari karyawan korbaan PHK di kota Balikpapan. Data yang dikumpulkan berupa narasi deskriptif yang didapatkan dari wawancara tidak terstruktur dan observasi lapangan. Wawancara dilakukan pada bulan Agustus tahun 2020. Setelah data dilakukan triangulasi, data di analisis untuk dihasilkan tawaran solusi keberlanjutan usaha.

\section{HASIL DAN PEMBAHASAN}

Kondisi yang menggambarkan hambatan dan persoalan tergambar pada profil yang terbagi dalam beberapa hal, yaitu produktifitas, segmentasi pasar, pemasaran, distribusi dan teknologi produksi.

\subsection{Produktifitas dan manajemen}

Produktifitas dan omset belum stabil karena belum menemukan pola pasar yang jelas.Varian dan model kemasannya juga masih terlalu umum, belum menunjukan keunikan dan kebaharuan dan trend.Padahal alat yang dimiliki Mitra punya kapasitas produksi berbagai varian produk roti. Mitra belum memiliki peralatan dan alat kebersihan yang menunjang proses pembuatan roti selama masa pandemi Covid 19.

\subsection{Segmentasi konsumen}

Rencana awal segmentasi pasar yang disasar Mitra adalah toko, kantin sekolah/kampus, kantin rumah sakit, supermarket, paket rapat kantor dan masyarakat umum via media sosial. Kondisi pandemi COVID 19 semakin mempersulit UKM tersebut untuk mencari pasar karena hampir semua instansi baik sekolah, perkantoran, dan kantin rumah sakit tutup.Selain itu analisis trend minat konsumen dalam rangka inovasi diversifikasi produk belum dilakukan dengan tepat. Sedangkan segmentasi pasar Mitra B adalah masyarakat umum via media sosial sebatas Whatsapp Group.

\subsection{Pemasaran}

Selain sistem pemasaran konvensional melalui penawaran secara lisan ke warung warung dan toko - toko, pemasaran juga menggunakan media sosial whatsapp group, facebook dan instagram (@twinshafizh_bakery) namun belum memenuhi standar manajemen pemasaran yang efektif sesuai potensi platform media sosial yan ada.Pesanan yang ada sejauh ini didominasi oleh teman - teman dekat yang mungkin melakukan transaksi karena rasa empati belum ke konsumen rasional. Belum adanya sertifikat PIRT menyebabkan tidak bisa masuk ke supermarket jaringan lokal Balikpapan (MAXI, YOVA Mart, SUSANA) maupun supermarket jaringan nasional (Alfamidi, Indomaret, dll).

\subsection{Sistem distribusi}

Sistem pengantaran produk ke konsumen pada Mitra masih konvensional, yakni diantar langsung oleh pemilik usaha ke konsumen dengan motor. Hal ini tentu tidak efisien dari segi waktu dan tenaga. Keterlibatan komunitas kurir diharapkan menghasilkan multiplier effect yang lebih luas, terlebih komunitas kurir baik berpaltform aplikasi (Grab, Gocar, 
Maxim) (Mariana, 2020) maupun non aplikasi (komunitas kurir Balikpapan) yang sudah mulai tumbuh di kota Balikpapan, terlebih di saat pandemi COVID 19.

Dari analisis situasi diata, maka solusi yang ditawarkan terkait dengan prioritas permasalahan adalah sebagai berikut.

\section{Solusi Aspek Manajerial}

Pendampingan pengurusan sertifikasi PIRT untuk kedua Mitra akan dilakukan untuk peningkatan mutu produk dan perluasan sistem pemasaran ke toko modern dikarenakan PIRT menjadi syarat utama sebuah produk bisa dipasarkan secara luas ke berbagai macam saluran distribusi. Regulasi yang mengatur PIRT di kota Balikpapab adalah Peraturan Walikota Balikpapan No. 23 Tahun 2018 tentang Perubahan atas Peraturan Walikota Nomor 18 Tahun 2017 tentang Pendelegasian Kewenangan Pelayanan Perizinan dan Non Perizinan Kepada DPMPT (Dinas Penanaman Modal dan Perizinan Terpadu).

Penyuluhan dan pendampingan terkait manajemen produksi akan dilakukan oleh anggota tim untuk membantu Mitra mengatur produksi yang efisien. Selain itu dibidang manajemen keuangan, Mitra akan dibantu melalui aplikasi penjualan berbasis Microsoft Visual Studio 6.0 dan Microsoft Visual Studio 2010. Jika sewaktu - waktu butuh pengembangan usaha, pelaporan keuangan usaha dapat dijadikan penguat proposal pendanaan ke bank maupun lembaga permodalan yang lain. Penguatan manajemen keuangan melalui standar pengelolaan keuangan UKM diperlukan agar monitoring evaluasi laba-ruginya dilakukan dengan mudah dan efisien.

\section{Solusi Aspek Akses Permodalan}

Memberikan bantuan akses perbankan dengan skema bunga subsidi melalui pembuatan laporan keuangan yang standar sehingga dapat digunakan untuk mengajukan pinjaman perbankan. Skema pinjama usaha bisa melalui kredit UMKM KUR, atau pendampingan untuk mengajukan bantuan permodalan dari dinas terkait.

Sebagai pengendalian bantuan permodalan, ketika bantuan ini diberikan, Mitra diharapkan dapat melaporkan dan memasukkan ke dalam database aplikasi Micsosoft Excel (sebagai aplikasi aspek manajerial) agar bisa termonitor aliran cachflownya. Namun penggunaan teknologi ini menyesuaikan kebutuhan dilapangan.

3. Solusi Aspek Teknologi Pemasaran/ Distribusi

Implementasi teknologi pemasaran terhadap mitra akan dilakukan meliputi hal - hal:

a. Redesign platform instagram (@twinshafizh_bakery) dan facebook (Twins Hafizh Bakery) dengan mendaftarkan akun INSTAGRAM dan FB bisnis dan berbayar. Tampilan design foto display makanan akan didesign ulang dan rapikan agar tampilannya menjadi menarik.

b. Untuk sistem distribusi penjualan barang, mitra didorong untuk bekerjasama dengan komunitas kurir Balikpapan.

c. Mitra didaftarkan ke dalam aplikasi GoFood dan GrabFood agar segmen pasar bisa berkembang dan menyasar ke banyak konsumen. 
Luaran yang terukur untuk setiap solusi, tergambar dalam Tabel 1 berikut ini.

Tabel 1 Analissi Aspek Masalah, Solusi dan Sasaran

\begin{tabular}{|c|c|c|}
\hline ASPEK & SOLUSI & SASARAN \\
\hline Aspek Manajerial & $\begin{array}{l}\text { 1. Pendampingan Pengurusan PIRT. } \\
\text { 2. PendampinganManajemen } \\
\text { Produksi } \\
\text { 3. Pendampingan Manajemen } \\
\text { Keuangan. }\end{array}$ & $\begin{array}{l}\text { 1. Ijin PIRT dari DPMPT. } \\
\text { 2. Implementasi aplikasi manajemen } \\
\text { produksi-penjualan sederhana }\end{array}$ \\
\hline $\begin{array}{c}\text { Aspek } \\
\text { Permodalan }\end{array}$ & $\begin{array}{l}\text { 1. Pembelian barang modal. } \\
\text { 2. Dana modal untuk peningkatan } \\
\text { produksi. }\end{array}$ & $\begin{array}{l}\text { 1. Barang modal berupa kulkasshow } \\
\text { case, mixer doughdan peralatan } \\
\text { lainnya untuk Mitra A. Peralatan } \\
\text { produksi siomay udang serta deep } \\
\text { freezeruntuk Mitra B. } \\
\text { 2. Dana modal tunai untuk } \\
\text { peningkatan kapasitas produksi. }\end{array}$ \\
\hline $\begin{array}{l}\text { Aspek Teknologi } \\
\text { Pemasaran/ } \\
\text { Distribusi }\end{array}$ & $\begin{array}{l}\text { 1. Redesign \& pembuatan akun IG \& } \\
\text { FB. } \\
\text { 2. Kerjasama dengan komunitas } \\
\text { Balikpapan Foodies. } \\
\text { 3. Pendaftaran ke aplikasi GrabFood } \\
\text { atau GoFood. } \\
\text { 4. Pembuatan box motor delivery. }\end{array}$ & $\begin{array}{l}\text { 1. Akun IG dan FB bisnis } \\
\text { (berbayar). } \\
\text { 2. Kontrak kerjasama dengan } \\
\text { komunitas Balikpapan Foodies. } \\
\text { 3. Terdaftar di akun GrabFood atau } \\
\text { GoFood. } \\
\text { 4. Unit sepeda motor terpasang box } \\
\text { motor delivery. }\end{array}$ \\
\hline
\end{tabular}

Sedangkan penggunaan teknologi pemasaran dan distribusi sesuai tingkat kebutuhan mitra disajikan beberapa rencana implementasi sebagai berikut.

Tabel 2 Implementasi Teknologi dan Pemasaran

\begin{tabular}{|c|c|c|}
\hline $\begin{array}{l}\text { PENERAPAN } \\
\text { TEKNOLOGI }\end{array}$ & DESKRIPSI & INDIKATOR CAPAIAN \\
\hline $\begin{array}{l}\text { Aplikasi manajemen } \\
\text { produksi-penjualan sederhana } \\
\text { berbasis Microsoft Visual } \\
\text { Studio } 6.0 \text { dan Microsoft } \\
\text { Visual Studio } 2010\end{array}$ & $\begin{array}{l}\text { Perhitungan produksi \& } \\
\text { pertanggung jawaban } \\
\text { keuangan yang mudah dan } \\
\text { efisien. }\end{array}$ & $\begin{array}{l}\text { 1. Memiliki aplikasi penjualan yang } \\
\text { mudah dan efisien. } \\
\text { 2. Terciptanya pelaporanlaba rugi \& } \\
\text { pencatatan keuangan yang akurat. } \\
\text { 3. Efisiensi proses produksi (bahan } \\
\text { baku, tenaga kerja, dll). }\end{array}$ \\
\hline $\begin{array}{c}\text { IG dan FB bisnis } \\
\text { Pada Mitra A dan Mitra B }\end{array}$ & $\begin{array}{l}\text { Design FB dan IG yang } \\
\text { menarik diharapkan mampu } \\
\text { menarik segmen pasar }\end{array}$ & $\begin{array}{l}\text { 1. Memiliki akun FB dab IG bisnis. } \\
\text { 2. Meningkatnya wawasan pemasaran } \\
\text { berbasis platform media sosial FB } \\
\text { dan IG. } \\
\text { 3. Peningkatan permintaan }\end{array}$ \\
\hline
\end{tabular}


4. Peningkatan omzet penjualanKenaikan kapasitas produksi per hari.

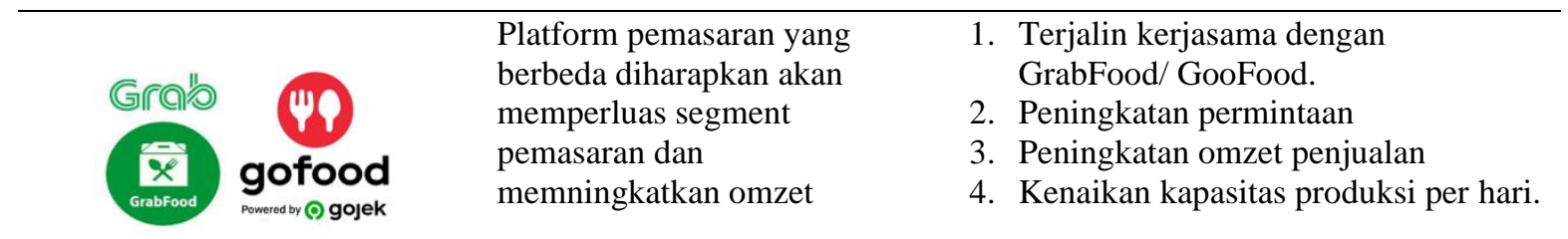

GrabFood atau GoFood

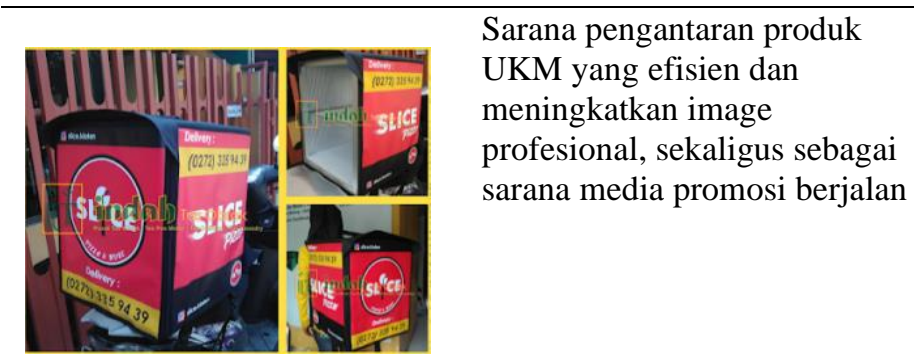

1. Mita memiliki alat pengantar produk yang efisen.

2. Peningkatan imej profesionlaitas UKM

Motor Box untuk distribusi pesanan Mitra A

Tiga aspek tawaran solusi diatas dapat diimplementasikan dalam skema kegiatan pengabdian yang ditawarkan ke mitra disesuaikan dengan kondisi perkembangan yang ada. Keberhasilan suatu usaha tidak terletak pada canggihnya alat dan besarnya modal yang dimiliki, tetapai bagaimana mampu membaca peluang dan potensi untuk di kelola sesuai kapasitas yang ada. Artikel ini merupakan analisis eksplorasi dan dokumentasi tawaran solusi sesuai kondisi mitra saat pengambilan data. Oleh karena itu tingkat kebutuhan solusi dapat sewaktu- waktu berubah sesuai dinamika di lapangan.

\section{KESIMPULAN}

Studi ini memberikan analisis situasi dan kebutuhan solusi atas usaha yang didirikan oleh karyawan yang kena kebijakan PHK perusahaan. Usaha yang didirikan merupakan usaha baru yang masuk kategori Usaha Kecil dan Menengah (UKM). Solusi yang diajukan terbagi dalam beberapa hal, yaitu manajerial, akses permodalan, dan implentasi teknologi pemasaran. Analisis eksplorasi dan dokumentasi tawaran solusi sesuai kondisi mitra saat pengambilan data. Oleh karena itu tingkat kebutuhan solusi dapat sewaktuwaktu berubah sesuai dinamika di lapangan.

\section{.DAFTAR PUSTAKA}

Afridhal, M. (2017). Strategi Pengembangan Usaha Roti Tanjong di Kecamatan Samalanga Kabupaten Bireuen. Jurnal Sains Pertanian, 1(3).

Efriyenty Hikmah; Khadijah, Khadijah, D. H. (2021). Pembinaan Pemasaran Digital dan Peningkatan Kualitas Laporan Keuangan pada Umkm Rafflesia di Kota Batam. ABDI SABHA (Jurnal Pengabdian Kepada Masyarakat), (Vol 1, No 2 
(2021): Februari), 105-109. Retrieved from

https://jurnal.ceredindonesia.or.id/index.php/jas/article/view/129/146

Lape Ngatu, E. V. (2019). ANALISIS KINERJA KEUANGAN PADA USAHA MIKRO KECIL DAN MENENGAH (UMKM ) TOKO ROTI FADHILAH DI KELURAHAN TLOGOMAS KOTA MALANG. JURNAL AGREGAT, (Vol 4, No 2 (2019)). Retrieved from

https://publikasi.unitri.ac.id/index.php/ekonomi/article/view/2189

Mariana, H. (2020). Begini Upaya Grab Menudukung UMKM di Kota Balikpapan. Kompas Online. Retrieved from https://money.kompas.com/read/2020/07/07/213922226/begini-upaya-grabdukung-umkm-di-balikpapan?page=all

Peraturan Walikota Balikpapan No. 23 Tahun 2018 tentang Perubahan atas Peraturan Walikota Nomor 18 Tahun 2017 tentang Pendelegasian Kewenangan Pelayanan Perizinan dan Non Perizinan Kepada DPMPT 